\title{
Tirotropintermelő hypophysisadenoma
}

\author{
Sohár Gábor dr. ${ }^{1}$ - Györkös Andrea dr. ${ }^{1}$ - Dóczi Tamás dr. ${ }^{2}$ \\ Kajtár Béla dr. ${ }^{3}$ - Piski Zalán dr. $^{4}$ - Kovács Mónika dr. ${ }^{1}$ \\ 'Zala Megyei Szent Rafael Kórház, I. Belgyógyászati és Infektológiai Osztály, Zalaegerszeg \\ ${ }_{2}^{2}$ Pécsi Tudományegyetem, Általános Orvostudományi Kar, Klinikai Központ, Idegsebészeti Klinika, Pécs \\ ${ }^{3}$ Pécsi Tudományegyetem, Általános Orvostudományi Kar, Klinikai Központ, Pathologiai Intézet, Pécs \\ ${ }^{4}$ Pécsi Tudományegyetem, Általános Orvostudományi Kar, Klinikai Központ, \\ Fül-Orr-Gégészeti és Fej-Nyaksebészeti Klinika, Pécs
}

\begin{abstract}
A tirotropintermelő hypophysistumor a hyperthyreosis ritka oka, a hypophysisadenomák 1 százalékában fordul elő. Az utóbbi években a felismert esetek száma nőtt az ultraszenzitív immunometriás esszék elterjedésének köszönhetően. A klinikai gyakorlatban a normál- vagy emelkedett tirotropinérték mellett észlelt emelkedett perifériás pajzsmirigyhormonszintek esetében kell felvetni a tirotropintermelő tumor lehetőségét. A szerzők egy középkorú nőbeteg esetét ismertetik, akinél a centrális hyperthyreosis hátterében tirotropintermelő hypophysis-macroadenoma igazolódott. Átmeneti thyreostaticus kezelést követően a tumor radikális idegsebészeti eltávolítása megtörtént. A műtétet követően a beteg hyperthyreosisa megszűnt, a residualis hypophysisfunkció megtartott maradt. Gondozása során recidívára utaló eltérést nem észleltünk. Esetismertetésünkben a kórkép felismerése kapcsán felmerülő differenciáldiagnosztikai nehézségeket is taglaljuk.
\end{abstract}

Orv Hetil. 2020; 161(12): 474-478.

Kulcsszavak: hyperthyreosis, hypophysisadenoma, hypophysismútét

\section{Thyrotropin-secreting pituitary adenoma}

Thyrotropin-secreting pituitary tumors are rare causes of hyperthyroidism and account for less than $1 \%$ of all pituitary adenomas. The number of reported cases increased over the last few years as a consequence of the routine use of ultrasensitive immunometric assays for measuring thyrotropin levels. In the clinical practice, thyrotropin secreting adenomas must be considered in case of inappropriately normal to elevated thyrotropin in the presence of elevated free serum thyroid hormone levels. The authors present the case history of a middle aged female patient, who suffered from hyperthyreodism caused by a thyrotropin-secreting pituitary macroadenoma. After transient thyreostatic treatment, radical neurosurgical removal of the tumor was performed. The pituitary surgery was effective in restoring the patient's euthyreodism. The postoperative pituitary function remained intact. During follow-up, the recurrence of the disease was not detected. In our case report, the difficulties in the differential diagnoses are also discussed.

Keywords: hyperthyreosis, hypophysis adenoma, pituitary surgery

Sohár G, Györkös A, Dóczi T, Kajtár B, Piski Z, Kovács M. [Thyrotropin-secreting pituitary adenoma]. Orv Hetil. 2020; 161(12): 474-478.

(Beérkezett: 2019. december 1.; elfogadva: 2019. december 30.)

\begin{abstract}
Rövidítések
ACTH $=$ (adrenocorticotropic hormone) adrenokortikotrop hormon; anti-TPO = tireoperoxidáz elleni antitest; FSH = folliculusstimuláló hormon; FT3 = szabad trijód-tironin frakció; FT4 = szabad tetrajód-tironin frakció; GH = (growth hormone) növekedési hormon; IGFl = (insulin-like growth factor 1) inzulinszerü növekedési faktor-1; LH = luteinizáló hormon; MRI = (magnetic resonance imaging) mágnesesrezonanciaképalkotás; SHBG = (sex hormon-binding globulin $)$ nemihor-
\end{abstract}

mon-kötő globulin; TRAK = TSH-receptor elleni antitest; $\mathrm{TRH}=$ (thyrotropin-releasing hormone) tirotropinfelszabadító hormon; $\mathrm{TSH}=$ tirotropin

A centrális hyperthyreosist okozó tirotropin (TSH)-termelö hypophysisadenoma a hyperthyreosis ritka oka [1]. A betegség első esetleírása 1960-ból származik [2]. A kórkép prevalenciája 1-2/millió lakos; a hypophysis- 
adenomák 1 százalékában fordul elō, és a 4-6. életévtizedben a leggyakoribb [3]. A férfi/nő arány közel azonos [3]. A TSH-termelő tumor csaknem mindig benignus, az esetek döntő többségében (70-80\%) macroadenomáról van szó [4]. Korábban a betegséget gyakran a hypophysistumor okozta kompressziós tünetek hátterében fedezték fel. Napjainkban a labordiagnosztika fejlődésével a kórkép általában korábbi stádiumban kerül felismerésre [2]. A betegségben a TSH-szekréció autonóm és refrakter a perifériás pajzsmirigyhormonok negatív feedback hatásával szemben [5]. A hyperthyreosis tünetei általában enyhébbek, mint a Graves-Basedow-kóros betegek esetében; struma gyakran társul a kórképhez, endocrin orbitopathia viszont soha nem fordul elő [6]. A betegség elsődleges kezelési módja a tumor sebészeti eltávolítása, második vonalbeli kezelésként szomatosztatinanalógok, illetve hypophysisirradiáció jön szóba $[7,8]$. Esetünkben centrális hyperthyreosis igazolódott, melynek hátterében TSH-termelő hypophysismacroadenomát diagnosztizáltunk. A tumor idegsebészeti eltávolítását követően a beteg hyperthyreosisa megszűnt, a hypophysisfunkció megtartott maradt.

\section{Esetismertetés}

A 46 éves nőbeteg kórelőzményében 2002-ben hüvelyplasztikai mütét szerepelt, gyógyszert rendszeresen nem szedett, családi anamnézise pajzsmirigybetegség vonatkozásában negatív volt. Endokrinológiai szakrendelésünkön 2015 májusában jelentkezett hyperthyreosisra utaló pajzsmirigyfunkciós laborértékei miatt. A betegnek hyperthyreosisra utaló panasza nem volt, fizikális vizsgálattal kóros eltérést nem észleltünk. Laborleleteiből emelkedett TSH (TSH: 4,01 mU/1, normális tartomány: 0,4-3,2 $\mathrm{mU} / \mathrm{l}$ ) és perifériás pajzsmirigyhormonértékek (FT4: 24,6 pmol/1, normális tartomány: 9,123,8 pmol/1; FT3: 13,3 pmol/1, normális tartomány: 2,2-6,5 pmol/1) voltak kiemelhetők. A nyaki ultrahang finoman inhomogén szerkezetü, mérsékelten vaszkularizált, normál méretű pajzsmirigylebenyeket mutatott göb nélkül. Tekintettel a beteg panaszmentességére, egy hónap múlva megismételt laborleletekkel visszarendeltük szakrendelésünkre. A kontrollvizsgálat során a beteg izzadékonyságra, szapora szívverésre, alvászavarra panaszkodott. Laborleletei a hyperthyreosis vonatkozásában progressziót mutattak: TSH: 4,60 mU/1, FT4: 38,46 pmol/1, FT3: 14,94 pmol/1. A tireoperoxidáz elleni (anti-TPO) és TSH-receptor elleni (TRAK) antitestek negatívak voltak (anti-TPO: 6,63 IU/ml, normális tartomány: 0-30 IU/ml, TRAK: 1,33 IU/1, normális tartomány: 0-1,5 IU/1). A hyperthyreosisra utaló klinikai tünetek és a laborleletek alapján $2 \times 10 \mathrm{mg}$ tiamazol- és $2 \times 40 \mathrm{mg}$ propranololkezelést kezdtünk. A centrális hyperthyreosis gyanúja miatt 2015 júniusában elvégzett, a hypophysist vizsgáló mágnesesrezonancia-képalkotás $(\mathrm{MRI})$ a sellát kitöltő $10 \mathrm{~mm} \times 11 \mathrm{~mm} \times 10,6 \mathrm{~mm}$ kiterjedésű kóros képletet ábrázolt, mely a hypophysis állo- mányát jobbra diszlokálta, a chiasma opticumot nem érte el és nem komprimálta (1. ábra). A látótér vizsgálata ép viszonyokat jelzett. Az elülső hypophysislebeny hormonális funkciójának károsodására utalóan a betegnek hypadreniára, illetve diabetes insipidusra jellemző klinikai tünete nem volt. Kis dózisú 'overnight' dexametazonszuppressziós teszt alapján (l mg dexametazon 24 órakor bevéve) hypercorticizmus nem igazolódott (szérumkortizol: $13 \mathrm{nmol} / 1$, 'cut-off' érték: $50 \mathrm{nmol} / \mathrm{l}$ ). A menstruációs ciklus harmadik napján elvégzett hormonmeghatározások hypogonadismust nem igazoltak (folliculusstimuláló hormon [FSH]: 5,388 $\mathrm{mIU} / \mathrm{ml}$, normális tartomány: 3-8,1 mIU/1; luteinizáló hormon [LH]: 4,954 $\mathrm{mIU} / \mathrm{ml}$, normális tartomány: 1,9-9,2 $\mathrm{mIU} / \mathrm{l}$; ösztrogén: $42,79 \mathrm{pg} / \mathrm{ml}$, normális tartomány: $85-498 \mathrm{pg} / \mathrm{ml}$ ). A beteg mérsékelt hyperprolactinaemiája a tumoros hypophysisnyél-kompresszió következménye lehetett (prolaktin: 643,4 mIU/1, normális tartomány: 132-511 mIU/1). Bár a betegnek acromegaliára utaló fizikális tünete, panasza nem volt, az inzulinszerű növekedési faktor-1 (IGF1) értéke emelkedést mutatott (IGFl: $875 \mathrm{ng} / \mathrm{ml}$, normális tartomány: 88-209 ng/ $\mathrm{ml})$. Négyhetes thyreostaticus kezelést követően a beteg izzadékonysága, szapora szívverése megszűnt, és pajzsmirigyfunkciós értékei is javultak (TSH: 5,12 mU/1, FT4: 21,16 pmol/1, FT3: 7,90 pmol/l), majd a tiamazolkezelés folytatása mellett a beteg euthyreoiddá vált (TSH: 1,1 mU/1, FT4: 13,4 pmol/1, FT3: 4,8 pmol/1).

Mivel a leletek a TSH-termelö hypophysisadenoma mellett szóltak, idegsebészeti konzílium történt, mely mútétet javasolt. A preoperatív vizsgálatok elvégzését követően 2015 októberében transsphenoidalis feltárásból endoszkópos technikával a hypophysistumor radikális eltávolítása megtörtént. A beavatkozást követően akut

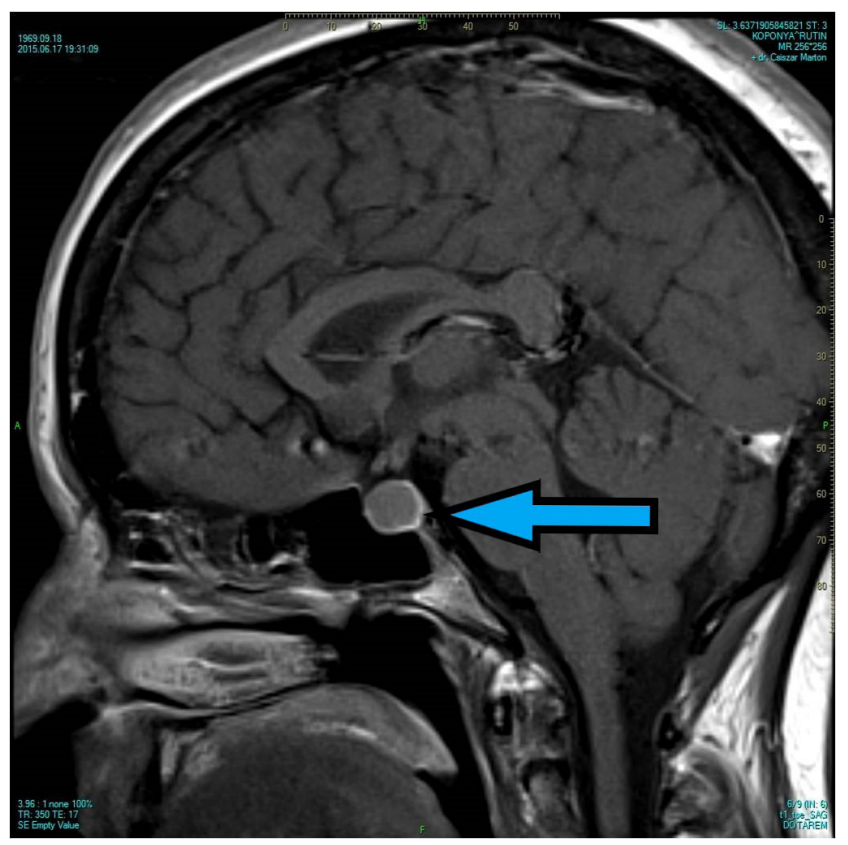

1. ábra $\quad$ Preoperatív hypophysis MRI felvétel 


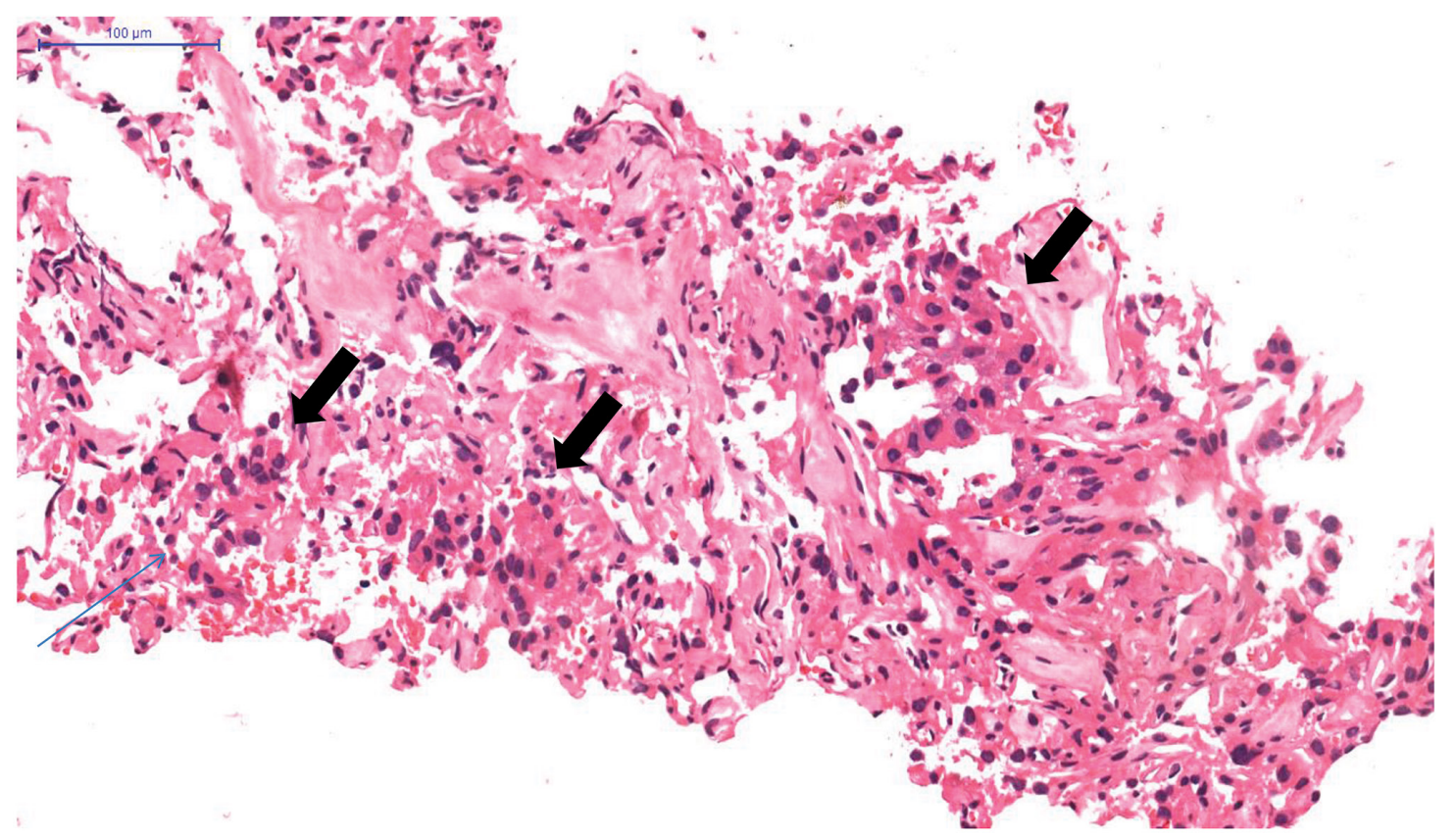

2. ábra $\mid$ Szövettani morfológia. HE-festés, 200x-os nagyítás. A képen fibroticus környezetben elhelyezkedő, eosinophil citoplazmájú sejtekből álló, zilált sejtfészkek észlelhetők (nyilak)

HE = hematoxilin-eozin

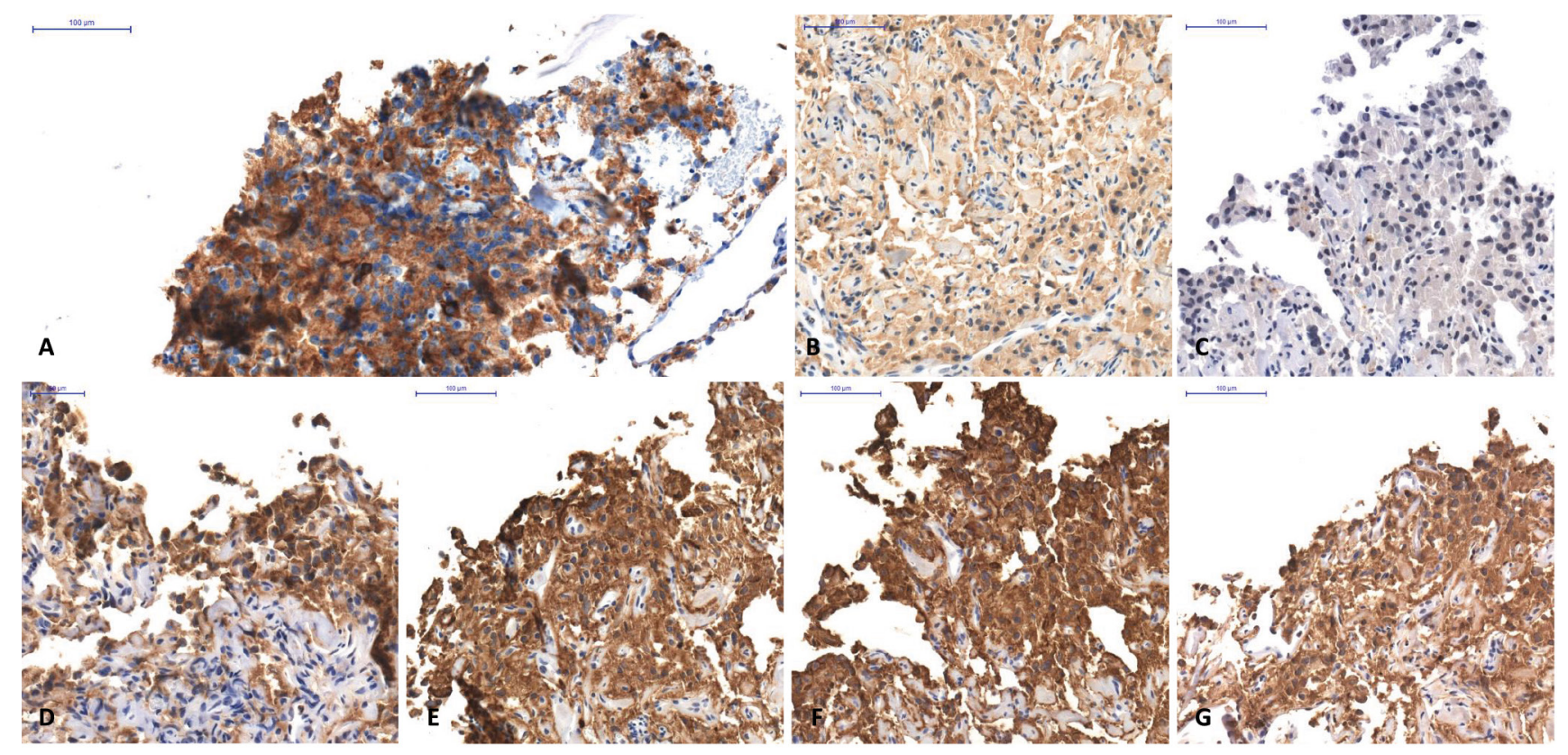

3. ábra $\quad$ Immunhisztokémiai reakciók. A képek 200×-os nagyításnak felelnek meg. A) Kromogranin A-pozitivitás; B) GH-negativitás (háttérjelölődés); C) ACTH-negativitás; D) FSH-pozitivitás; E) LH-pozitivitás; F) TSH-pozitivitás; G) PRL-pozitivitás

ACTH = adrenokortikotrop hormon; FSH = folliculusstimuláló hormon; GH = növekedési hormon; LH = luteinizáló hormon; PRL = prolaktin; $\mathrm{TSH}=$ tirotropin

szövődményt nem észleltek, diabetes insipidus nem alakult ki. Egy apró szövetrészleten került sor szövettani vizsgálatra, mely egy mechanikailag kissé károsodott, fészkes elrendeződést mutató, halványan eosinophil citoplazmájú, kerek magvú citológiai atípiát, mitotikus ak- tivitást, nekrózist nem mutató sejtekből álló tumorszövetet igazolt (2. ábra). A tumor stromája kifejezetten hialinizált, fibroticus volt, a Mibl-jelölődés 1\% alatti arányú volt, immunhisztokémiailag a sejtek kromogranin-, TSH-, LH-, FSH- és prolaktinpozitívak, továbbá az ad- 
renokortikotrop hormon (ACTH) és a növekedési hormon $(\mathrm{GH})$ negatívak voltak (3. ábra).

A posztoperatív hatodik héten a residualis hypophysisfunkció felmérése megtörtént (szérumkortizol: 410,9 nmol/1, normális tartomány: 140-640 nmol/1, ACTH: $22,25 \mathrm{pg} / \mathrm{ml}$, normális tartomány: $4-28 \mathrm{pg} / \mathrm{ml}, \mathrm{GH}$ : $6,6 \mathrm{ng} / \mathrm{ml}$, normális tartomány: 0,06-6,88 ng/ml, IGFl: $586 \mathrm{ng} / \mathrm{ml}$, FSH: $6,309 \mathrm{mIU} / \mathrm{ml}, \mathrm{LH}: 6,514$ $\mathrm{mIU} / \mathrm{ml}$, prolaktin: $382,6 \mathrm{mIU} / \mathrm{l}$; ösztrogén: 131,2 $\mathrm{pg} / \mathrm{ml})$. A beteg panaszmentes volt, leletei mellékveseelégtelenségre nem utaltak, TSH-, FT4-, FT3-értéke euthyreosist jelzett, emiatt gyógyszeres terápiát nem javasoltunk (TSH: 2,05 mU/1, FT4: 15,2 pmol/1, FT3: $5,50 \mathrm{pmol} / \mathrm{l})$. A hypophysismútétet követően három hónappal kontroll-hypophysis-MRI történt, ez a hypophysis bal oldalában egy 5,5 × 3,5 mm nagyságú, a környező hypophysisállománynál kevésbé halmozó képletet ábrázolt, mely a chiasma opticumot nem érte el, nem komprimálta (4. ábra). Az MRI-lelet birtokában idegsebészeti kontroll történt, amelyen fél év múlva kontroll-MRI elvégzését javasolták, mivel a látott kép alapján residualis tumor nem volt kizárható. 2016 augusztusában az újabb hypophysis-MRI a bal lebenyben a korábbi vizsgálathoz képest változatlan residualis elváltozást ábrázolt. Az idegsebész progresszió hiányában a beteg további követését javasolta, véleménye szerint az MRI-n a reszekciós üreg posztoperatív nem halmozó területnek ábrázolódott. Ezt követően a beteget évente kontrolláljuk szakrendelésünkön, továbbra is panaszmentes, euthyreoid állapotban van, MRI-kontrollvizsgálatok során a korábbiaknak megfelelő mütét utáni status került leírásra.

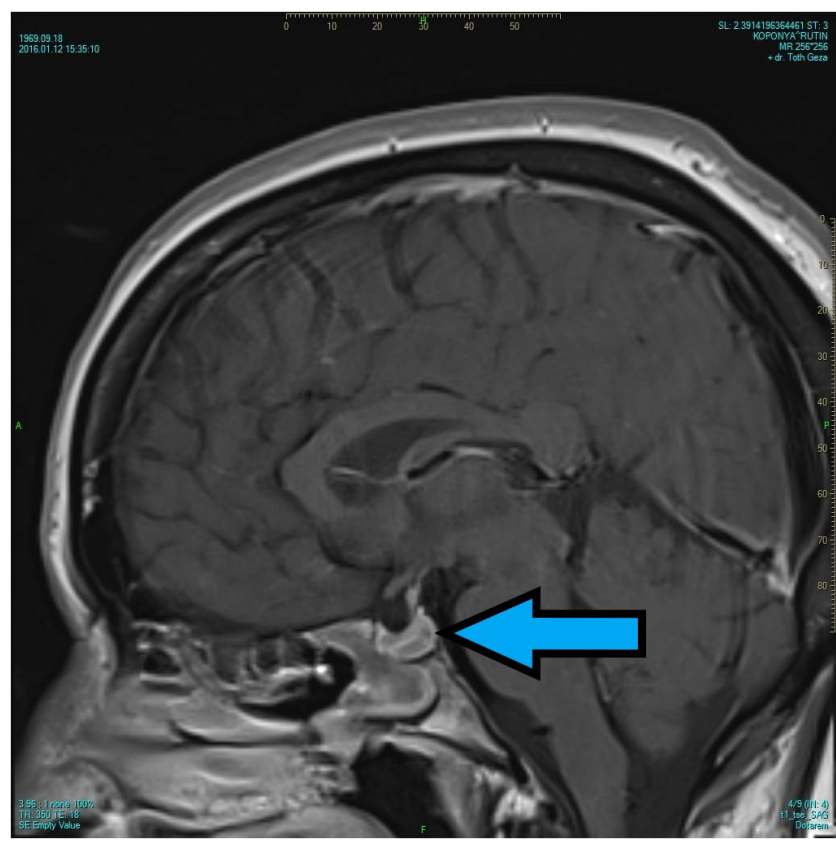

4. ábra

| Postoperatív hypophysis MRI felvétel

\section{Megbeszélés}

A centrális hyperthyreosis felismerése a klinikusok számára több szempontból is differenciáldiagnosztikai nehézséget okozhat. Ugyanis a T4 vagy a T3 ellen termelődő autoantitestek megtévesztően magas T4/T3 koncentrációkat okozhatnak, és a TSH elleni antitestek szintén téves eredményhez vezethetnek [4]. Segítséget jelenthet, ha olyan laboratóriumban is elvégzik a minta elemzését, ahol a sajáttól eltérő analitikai módszert használnak [3]. A hypothyreosis miatt levotiroxinnal kezelt beteg esetén a mért emelkedett TSH- és FT4-értékek a beteg nem megfelelő gyógyszerszedését jelezhetik, hiszen az FT4-érték emelkedett lehet a vérvétel előtt nagyobb mennyiségű gyógyszerbevétel következményeként [1]. Az antiaritmiás szerként használt amiodaron szintén okozhat hasonló laboreltérést a T4-T3-átalakulás gátlása révén [3]. Ezekben az esetekben a gondos anamnézisfelvétel és a beteg gyógyszerelésének áttekintése segítséget jelenthet. Fontos elkülöníteni a centrális hyperthyreosist a pajzsmirigyhormon-rezisztenciától is, melyet a nemihormon-kötő globulin (SHBG) szintjének meghatározása és a kollagén-keresztkötés vizsgálata segíthet, ugyanis TSH-termelő adenomában ezek koncentrációja kórosan alacsony [3]. Pajzsmirigyhormonrezisztencia esetén gyakori $(80 \%)$ a családi halmozódás is [3]. A glikoprotein hormonok közös alfa-alegységének vizsgálata során a TSH-termelő adenomás betegeknél emelkedett értéket kapunk [6]. Differenciáldiagnosztikai szempontból ugyancsak hasznos lehet a TRH-teszt, illetve a T3-szuppressziós teszt elvégzése [6].

A TSH-termelő hypophysisadenomák $80 \%$-ban csak TSH-t, 10-15\%-ban GH-t és prolaktint is termelnek. Az immunhisztokémiai vizsgálattal észlelt pozitivitás nem feltétlenül társul a hormonok in vivo túltermelésével [1]. Esetünkben immunhisztokémiailag TSH- mellett FSH-, LH-, prolaktinpozitivitás is igazolódott; a preoperatív kivizsgálás kapcsán gonadotropin-túlprodukció jeleit nem észleltük, bár a beteg prolaktinértéke mérsékelten emelkedett volt - ennek hátterében a hypophysisnyél tumoros kompressziója merült fel. Érdekesség, hogy a laborvizsgálatok GH-hiperszekrécióra utaltak az emelkedett IGFl-érték alapján, a betegnek acromegaliod tünete nem volt, és immunhisztokémiai vizsgálat sem támasztotta alá a GH túltermelését. Nem zárható ki annak lehetősége, hogy az apró, mechanikai károsodást szenvedett mintán végzett immunhisztokémiai reakció álnegatív eredményt mutatott. A mütétet követően az IGFl-szint csökkent, majd a hat hónappal késóbbi kontroll során már normalizálódott (IGFl: $150 \mathrm{ng} / \mathrm{ml}$ ). Betegünknél a preoperatív kivizsgálást követően a hypophysistumor radikális eltávolítása megtörtént, ezt követően a beteg euthyreoid állapotba került. Irodalmi adatok alapján ebben a betegségben a mütéti megoldást követően 75-83 százalékban érhető el euthyreoid állapot [1]. Ha a hypophysisműtét elvégzése kontraindikált, vagy a beteg nem vállalja, második vonalbeli kezelésként hypophysisirradiáció 
vagy szomatosztatinanalógokkal végzett gyógyszeres kezelés jöhet szóba [9]. A radioterápia 2 éven belül a betegek 37\%-ában normalizálja a pajzsmirigyfunkciót [1]. A hosszú hatású szomatosztatinanalógokkal (oktreotid, lanreotid) végzett kezelés az esetek többségében szintén euthyreosist biztosít, és az esetek 50\%-ában tumorméret-csökkentő hatású is lehet [1].

Betegünket preoperatív közepes dózisú thyreostaticus terápia mellett euthyreoid állapotba tudtuk hozni, ezt követően történt az adenoma sebészeti eltávolítása. Amennyiben a beteg hyperthyreosisa klinikailag jelentős tüneteket okoz, akkor még az idegsebészeti beavatkozást megelőzően sebészeti vagy jódizotópos pajzsmirigy-ablatio, illetve thyreostaticumok adása is megkísérelhetó [6]. Ezen kezelési módok viszont mérséklik a pajzsmirigyhormonok által közvetített negatív visszacsatolást, ami a hypophysistumor növekedéséhez vezethet.

Irodalmi adatok alapján a sikeres sebészeti ellátást követően a TSH-termelő hypophysisadenoma kiújulása ritka [1]. A követés szempontjából az első posztoperatív évben 2-3 alkalommal klinikai és biokémiai kontroll javasolt, illetve 2-3 évente képalkotó vizsgálattal (hypophysis-MRI) való követés [1]. A hyperthyreosis recidívája esetén soron kívüli képalkotó vizsgálat elvégzése javasolt.

Az esetet egyrészt a kórkép ritka előfordulása, másrészt a kedvező terápiás kimenetel miatt tartottuk bemutatásra érdemesnek, kiemelve a centrális hyperthyreosis differenciáldiagnosztikai nehézségeit.

Anyagi támogatás: A közlemény megírása anyagi támogatásban nem részesült.

Szerzôi munkamegosztás: A kézirat megszövegezésében S. G. előkészítő munkáját követően a társszerzők egyenlő arányban vettek részt. A cikk végleges változatát valamennyi szerző elolvasta és jóváhagyta.

Érdekeltségek: A szerzőknek nincsenek érdekeltségeik.

\section{Irodalom}

[1] Beck-Peccoz P, Persani L, Lania A. Thyrotropin-secreting pituitary adenomas. Available from: http://ncbi.nlm.nih.gov/ books/NBK278978 [accessed: January 11, 2019].

[2] Brucker-Davis F, Oldfiled EH, Skaluris MC. Thyrotropin-secreting pituitary tumors: diagnostic criteria, thyroid hormone sensitivity and treatment outcome in 25 patients followed at the $\mathrm{Na}$ tional Institutes of Health. J Clin Endocrinol Metab. 1999; 84: 476-486

[3] Tóth M. TSH producing hypophysis adenoma. In: Leövey A, Nagy VE, Paragh Gy, et al. (eds.) Clinical practice hand-book of endocrinology and metabolism. [TSH-termelö hypophysis-adenoma. In: Leövey A, Nagy VE, Paragh Gy, et al. (szerk.) Az endokrin és anyagcsere-betegségek gyakorlati kézikönyve.] Medicina Könyvkiadó, Budapest, 2011; pp. 116-119. [Hungarian]

[4] Tjörnstrand A, Nyström FH. Diagnosis of endocrine disease: diagnostic approach to TSH-producing pituitary adenoma. Eur J Endocrinol. 2017; 177: R183-R197.

[5] Wacharasindhu S, Shuangshoti S, Sunthornyothin S. TSH-secreting pituitary macroadenoma in a girl with lingual thyroid. Case Rep Endocrinol. 2013; 2013: 570847.

[6] Beck-Peccoz P, Lania A, Beckers A, et al. 2013 European Thyroid Association guidelines for the diagnosis and treatment of thyrotropin-secreting pituitary tumors. Eur Thyroid J. 2013; 2013: 76-82.

[7] Ónnestam L, Berinder K, Burman P, et al. National incidence and prevalence of TSH-secreting pituitary adenomas in Sweden. J Clin Endocrinol Metab. 2013; 98: 626-635.

[8] Yamada S, Fukuhara N, Horiguchi K, et al. Clinicopathological characteristics and therapeutic outcomes in thyrotropin-secreting pituitary adenomas: a single-center study of 90 cases. J Neurosurg. 2014; 121: 1462-1473.

[9] Mezősi E, Nemes O. Treatment of pituitary adenomas. [A hypophysisadenomák kezelése.] Orv Hetil. 2009; 150: 1803-1810. [Hungarian]

\title{
ÁLLÁSAJÁNLAT
}

Tápiószecső Nagyközség Önkormányzata l-es háziorvosi körzetének

új rendelöjébe háziorvos jelentkezését várja. A praxis azonnal betölthető.

Az Önkormányzat 3 éven keresztül plusz havi 100000 Ft-ot térít, melyet lakásbérlésre vagy útiköltségre lehet felhasználni.

\author{
Érdeklődés telefonon: \\ Gál Csaba \\ 06203200142
}

A cikk a Creative Commons Attribution 4.0 International License (https://creativecommons.org/licenses/by/4.0/) feltételei szerint publikált Open Access közlemény, melynek szellemében a cikk bármilyen médiumban szabadon felhasználható, megosztható és újraközölhető, feltéve, hogy az eredeti szerző és a közlés helye, illetve a CC License linkje és az esetlegesen végrehajtott módosítások feltüntetésre kerülnek. (SID_1) 